THE ACQUISITION OF KNOWLEDGE 


\title{
THE ACQUISITION OF KNOWLEDGE
}

\author{
James Russell \\ Lecturer in Psychology \\ University of Liverpool
}

Macmillan Education 
ISBN 978-1-349-03050-7 ISBN 978-1-349-03048-4 (eBook)

DOI 10.1007/978-1-349-03048-4

(C) James Russell, 1978

Softcover reprint of the hardcover 1st edition 1978

All rights reserved. For information, write:

St. Martin's Press, Inc., 175 Fifth Avenue, New York, N.Y. 10010

Library of Congress Catalog Card Number 78-6881

ISBN 978-0-312-00273-2

First published in the United States of America in 1978

\section{Library of Congress Cataloging in Publication Data}

Russell, James, 1948-

The acquisition of knowledge.

Bibliography: $\mathrm{p}$.

Includes index.

1. Cognition. 2. Cognition in children. 3. Knowledge, Theory of. I. Title.
BF311.R87
$155.4^{\prime} 13$
$78-6881$

ISBN 978-0-312-00273-2 
To Christine, Charlotte and Patrick 


\section{Preface}

Because this book is something of a hybrid in that it deals with both psychological and philosophical topics, my problem in deciding how to pitch the presentation was particularly acute. If I had started with Piaget's theory then proceeded by way of Baldwin to philosophical questions about the nature of knowledge and thence to consider genetic epistemology the material might have proved more immediately accessible to those without a philosophical background but would have resulted in a less satisfactory whole: the logical and historical order would have been quite wrong. Therefore, my advice to a reader whose only perspective on these issues has been provided by a slight acquaintance with Piaget's developmental psychology and who does not feel ready to tackle the generalities is to read Part 2 and 3 first and then go on to Part 1 and 4. Also the psychological readership might feel some impatience with what they may regard as an over-detailed historical introduction in Section 1.1. I believe, however, that anything much briefer would have had to be so general or so elliptical as to be almost meaningless.

J. M. Baldwin's work is unfamiliar to the great majority of those with either a psychological or a philosophical interest in the acquisition of knowledge; and many of those who do know of it may feel that it is best left to languish in the murky prehistory of psychology. But I have given myself the task of introducing this work because I am certain that not only is it impossible to give a serious treatment of genetic epistemology without a full consideration of Baldwin but also that the theory is interesting and important in itself. The past 70 years of psychology have, if anything, increased rather than diminished its importance. As I say in Part 4 the aim is to give the theory a 'run for its money' not to advocate a wholesale adoption of his proposals. We cannot return to a cosier era of pre-behaviourism as some may like to think, but neither is psychology yet as cumulative a discipline as many more may like to believe!

I am very grateful to Professor D. W. Hamlyn, Professor L. S. Hearnshaw and Professor Wolfe Mays for reading and commenting on portions of an earlier draft of the book. These comments did in some cases influence the scope and emphasis of the text, though not the substance. 
viii

PREFACE

Thanks are also due to Mrs Myfanwy Thompson for preparing the final typescript so swiftly and well.

Chester, 1978

J.R. 


\section{Contents}

Preface vii

Introduction 1

Part 1: Philosophical Origins and Baldwin's Theory 15

1.1 The Problem of Knowledge 17

1.2 James Mark Baldwin and Genetic Epistemology $\quad 40$

1.2.1 Interest and datum $\quad 54$

1.2.2 Control, conversion and mediation $\quad 55$

1.2.3 Imitation $\quad 56$

1.2.4 Play $\quad 57$

1.2.5 Commonness: syndoxic meaning 59

1.2.6 From schema to general concept 59

1.2.7 Ideal meaning 61

1.2.8 Synnomic meaning $\quad 62$

1.2.9 Predication: and language $\quad 63$

1.2.10 Predication: elucidation and proposition $\quad 64$

1.2.11 Abstract and general terms 65

1.2.12 Propositions $\quad 67$

1.2.13 Implication and reflection 68

1.2.14 Limitation $\quad 69$

$\begin{array}{ll}1.2 .15 \text { Truth } & 70\end{array}$

1.2.16 Real logic $\quad 71$

1.2.17 Mediate and immediate knowledge $\quad 71$

1.2.18 Value and worth $\quad 73$

1.2.19 Ethical judgments and ideal meaning 73

$\begin{array}{ll}\text { 1.2.20 The moral as singular } & 75\end{array}$

1.2.21 Art $\quad 75$

1.2.22 Immediate knowledge-reconciliation $\quad 77$

$\begin{array}{ll}\text { 1.2.23 Kinds of reality } & 77\end{array}$

$\begin{array}{ll}\text { Part 2: Piaget's Theory } & 83\end{array}$

2.1 1910-1930: The Early Quest for Structures and Studies of Infancy 
2.21930 Onwards: Logico-mathematical Systems in Child and Adolescent Thinking and Genetic Epistemology

Part 3: Experiments

3.1 Object Permanence

3.2 Transitivity

3.3 Conservation

3.4 Language Acquisition

3.5 Overview

Part 4: Critique

4.1 Piaget's Structuralism 196

4.2 Baldwin's Philosophical Psychology 210

4.3 The Two Faces of Genetic Epistemology 216

4.4 Hypotheses 221

4.5 Against Cognitive Structuralism 233

4.6 Coda 248

4.6.1 Consciousness 249

4.6.2 Structures $\quad 257$

4.6.3 Motivation 263

4.6.4 Conventions and functions $\quad 269$

$\begin{array}{ll}\text { References } & 277\end{array}$

$\begin{array}{ll}\text { Index } & 291\end{array}$ 